\title{
Kesalahan Pemakaian Ejaan dalam Penulisan Autobiografi Mahasiswa Prodi S-1 Sastra Indonesia Universitas Diponegoro Angkatan 2019 Kelas A
}

\author{
Mujid Farihul Amin \\ Fakultas Ilmu Budaya, Universitas Diponegoro \\ mujidfib@gmail.com
}

\begin{abstract}
Errors in language can be seen from mistakes in relation to grammar and errors from the spelling angle. The parameters for assessing errors related to grammar are the rules in Indonesian Standard Grammar and for assessing errors related to spelling are the General Guidelines for Indonesian Spelling. In writing the autobiography of the students of $S-1$ Indonesian Literature Study Program 2019 Class A, from the spelling point there are still errors that include the use of letters, word writing, use of punctuation, and writing of absorption elements. For this reason, the ability to understand the rules in the Indonesian Spelling General Guidelines, accuracy, and accuracy needs to be improved.
\end{abstract}

Keywords: Errors; spelling; students; autobiography.

\section{Intisari}

Kesalahan dalam berbahasa bisa dilihat dari kesalahan dalam kaitannya dengan tata bahasa dan kesalahan dari sudut ejaan. Parameter untuk menilai kesalahan yang berkaitan dengan tata bahasa adalah aturan-aturan dalam Tata Bahasa Baku Bahasa Indonesia dan untuk menilai kesalahan berkait dengan ejaan adalah Pedoman Umum Ejaan Bahasa Indonesia. Dalam penulisan autobiografi para mahasiswa Prodi S-1 Sastra Indonesia Angkatan 2019 kelas A, dari sudut ejaan masih terdapat kesalahan-kesalahan yang mencakup pemakaian huruf, penulisan kata, pamakaian tanda baca, dan penulisan unsur serapan. Untuk itu, kemampuan untuk memahami kaidah-kaidah dalam Pedoman Umum Ejaan Bahasa Indonesia, kecermatan, dan ketelitian perlu ditingkatkan.

Kata kunci: Kesalahan; ejaan; mahasiswa; autobiografi.

\section{Pendahuluan}

Ragam Bahasa Indonesia apabila dipandang dari sudut sarana yang digunakan untuk menyampaikan dapat dibagi dalam dua golongan, yaitu ragam bahasa lisan dan ragam bahasa tulis. Kedua jenis ragam bahasa ini, tentu mempunyai perbedaan. Perbedaan mendasar adalah kalau ragam bahasa lisan disampaikan secara lisan dengan menggunakan alat ucap dan 
dipahami dengan cara didengarkan dengan indra pendengaran, tetapi ragam bahasa tulis disampaikan secara tertulis dengan cara ditulis dan dipahami dengan indra penglihatan.

Perbedaan lain antara ragam bahasa lisan dan tulis adalah kalau ragam bahasa lisan memungkinkan terjadinya pelesapan unsur-unsurnya tetapi masih dapat dipahami dan kalau ada kesalahan bisa langsung dibetulkan, tetapi kalau ragam tulis harus lengkap unsurunsurnya. Jadi, dalam ragam bahasa tulis harus lengkap fungsi-fungsi sintaksisnya dan harus tepat penulisannya.

Kesalahan dalam berbahasa dapat diklasifikasikan menjadi dua, yaitu kesalahan dalam bidang tata bahasa dan kesalahan terkait dengan ejaan. Parameter untuk menilai kesalahan dari sudut tata bahasa adalah kaidah-kaidah Tata Bahasa Baku Bahasa Indonesia (1998) dan kesalahan terkait dengan ejaan parameter untuk menilainya adalah aturan-aturan dalam Pedoman Umum Ejaan Bahasa Indonesia (2016).

Pumpunan penelitian ini adalah masalah ejaan. Ejaan adalah "pelambangan bunyibunyi bahasa dengan huruf, baik berupa huruf demi huruf maupun maupun huruf yang telah disusun menjadi kata, kelompok kata, atau kalimat” (Mustakim, 1996). Masalah ejaan yang diteliti adalah kesalahan penulisan dari sudut ejaannya.

Berkaitan dengan kesalahan dari sudut ejaan, berdasarkan hasil kajian yang telah peneliti laksanakan ternyata penulisan autobiografi yang disusun oleh para mahasiswa Prodi S-1 Sastra Indonesia Angkatan 2019 kelas A masih terdapat beberapa kesalahan. Oleh karena itu, peneliti tererak untuk meneliti lebih lanjut kesalahan-kesalahan apa saja yang masih terdapat dalam penulisan autobiografi para mahasiswa Prodi S-1 Sastra Indonesia Angkatan 2019 kelas A apabila dianalisis dengan menggunakan kaidah-kaidah/peraturan dalam Pedoman Umum Ejaan Bahasa Indonesia (2016).

\section{Metode Penelitian}

Penelitian ini adalah penelitian deskriptif kualitatif dengan objek penelitian berupa autobiografi mahasiswa Prodi S-1 Sastra Indonesia Angkatan 2019 peserta kuliah Bahasa Indonesia kelas A yang merupakan tugas mata kuliah Bahasa Indonesia. Penelitian ini dalam 
pelaksanaannya mengikuti tiga tahapan strategis yang disampaikan oleh Sudaryanto (1993), yaitu tahap pemerolehan data, analisis data, dan penyajian hasil analisis.

Pada tahap pemerolehan data, peneliti menggunakan metode simak dan teknik catat. Langkah yang ditempuh yaitu dengan menyimak autobiografi yang ditulis oleh para mahasiswa Prodi S-1 Sastra Indonesia Angkatan 2019 dan kemudian dilanjutkan dengan mencatat data-data yang terkait dan diperlukan dalam penelitian ini. Setelah data yang diperlukan terkumpul, data tersebut diklasifikasikan sesuai dengan jenis-jenis kesalahan ejaannya. Data yang sudah diklasifikasikan kemudian selanjutnya dianalisis. Data tersebut dianalisis dengan memakai dua metode, yakni metode normatif dan metode identitas. Setelah tahap analisis data selesai dilaksanakan, data siap untuk disajikan. Penyajian data dilakukan dengan menggunakan metode penyajian informal, yaitu sebuah metode penyajian dengan menggunakan kata-kata biasa tanpa memakai lambang-lambang.

\section{Hasil dan Pembahasan}

Berdasarkan kerja yang dilakukan pada tahap analisis data, maka dapat diidentifikasi kesalahan-kesalahan yang ada. Kesalahan-kesalahan pemakaian ejaan yang ada dalam penulisan autobigrafi mahasiswa Prodi S-1 Sastra Indonesia Angkatan 2019 Kelas A dapat dipaparkan sebagai berikut.

\section{Kesalahan Pemakaian Huruf}

Kesalahan pemakaian huruf meliputi kesalahan pemakaian huruf kapital dan huruf miring. Perhatikan data berikut.

(1) Dengan penuh harapan dan rasa cemas, Alhamdulillah aku diterima di Universitas Diponegoro, tepatnya program studi Sastra Indonesia.

(2) Awal masuk perkuliahan, tanggal 12 agustus setelah masa orientasi.

(3) Semoga kami bisa bertemu di Surga-Nya nanti.

(4) Di universitas Diponegoro saya mengambil jurusan Sastra Indonesia.

(5) ayah dan ibu saya adalah orang Jawa Tengah.

(6) Bahkan, aku menjawabnya dengan bahasa inggris.

Pada data (1)-(6) di atas, terdapat kesalahan pemakaian huruf, yang benar harusnya diketik dengan huruf kapital, tetapi diketik dengan huruf kecil. Pada data (1) tertulis program 
studi Sastra Indonesia, harusnya Program Studi S-1 Sastra Indonesia. Kemudian, pada data (2) tertulis tanggal 12 agustus, nama bulan ditulis dengan huruf awal kecil. Harusnya --sesuai dengan PUEBI - penulisan yang betul adalah tanggal 12 Agustus. Pada data (3), kata SurgaNya ditulis dengan huruf awal huruf kapital dan itu tidak sesuai dengan aturan yang ada di PUEBI, harusnya ditulis dengan huruf awal huruf kecil, yaitu surga-Nya. Selanjutnya, pada data (4), kata universitas dan jurusan, harusnya ditulis dengan huruf awal kapital karena kata tersebut diikuti nama. Jadi, yang betul adalah Universitas Diponegoro dan Jurusan Sastra Indonesia. Demikian pula pada data (5), kata ayah harusnya ditulis dengan huruf awal kapital karena kata tersebut terletak pada awal kalimat. Pada data (6), frasa Bahasa inggris harusnya ditulis menjadi Bahasa Inggris. Jadi, data (1)-(6) pembetulannya bisa dilihat pada (1a)-(6a) berikut.

(1a) Dengan penuh harapan dan rasa cemas, alhamdulillah aku diterima di Universitas Diponegoro, tepatnya Program Studi Sastra Indonesia.

(2a) Awal masuk perkuliahan, tanggal 12 Agustus setelah masa orientasi.

(3a) Semoga kami bisa bertemu di surga-Nya nanti.

(4a) Di Universitas Diponegoro saya mengambil Jurusan Sastra Indonesia.

(5a) Ayah dan ibu saya adalah orang Jawa Tengah.

(6a) Bahkan, aku menjawabnya dengan bahasa Inggris.

Pada data (7) dan (13) berikut, juga terdapat kesalahan penulisan huruf, yaitu kata-kata dari bahasa asing yang seharusnya dicetak/ditulis dengan huruf miring ternyata tidak dicetak dengan huruf miring.

(7) Sebelum berangkat aku wajib nonton power rangers, kalau tidak aku pasti tidak mau berangkat sekolah.

(8) Satu website aku buka untuk menepis semua pertanyaan itu.

(9) Demi Tuhan dia hanya membaca pesanku kemudian entah aku tidak tahu sepertinya dia memblokir akunku.

(10) Gapyear bukan suatu hal yang memalukan.

(11) Psikiater juga pernah masuk ke dalam list cita-cita saya, saya pikir saya ingin membantu orang-orang yang jiwanya sakit.

(12) Di SMA saya merasa sedikit minder karena saya berasal dari SMP Swasta yang ada di desa sedangkan kebanyakan dari teman-teman saya adalah lulusan dari SMP Negeri.

(13) Mereka adalah teman-teman yang sangat baik dan selalu saling mendukung jika salah satu diantara kita ada yang sedang down. 
Pada data (7), terdapat frasa power rangers yang merupakan frasa dari bahasa asing, harusnya ditulis dengan huruf miring menjadi power rangers. Demikian pula pada data (8)-(13), terdapat kata website, memblokir, gapyear, list, minder, dan down yang merupakan kata dari bahasa asing seharusnya sesuai kaidah harus ditulis dengan huruf miring menjadi website, mem-blokir, gapyear, list, minder, dan down. Jadi, penulisan yang betul bisa dilihat pada kalimat (7a) dan (13a) berikut.

(7a) Sebelum berangkat aku wajib nonton power rangers, kalau tidak aku pasti tidak mau berangkat sekolah.

(8a) Satu website aku buka untuk menepis semua pertanyaan itu.

(9a) Demi Tuhan dia hanya membaca pesanku kemudian entah aku tidak tahu sepertinya dia mem-blokir akunku.

(10a) Gapyear bukan suatu hal yang memalukan.

(11a) Psikiater juga pernah masuk ke dalam list cita-cita saya, saya pikir saya ingin membantu orang-orang yang jiwanya sakit.

(12a) Di SMA saya merasa sedikit minder karena saya berasal dari SMP Swasta yang ada di desa sedangkan kebanyakan dari teman-teman saya adalah lulusan dari SMP Negeri.

(13a) Mereka adalah teman-teman yang sangat baik dan selalu saling mendukung jika salah satu di antara kita ada yang sedang down.

\section{Kesalahan Penulisan Kata}

Kesalahan penulisan kata juga ada dalam penulisan autobiografi para mahasiswa Prodi S-1 Sastra Indonesia Angkatan 2019 kelas A. Kesalahan tersebut meliputi kesalahan penulisan preposisi, penulisan klitik, penulisan kata majemuk, penulisan angka dan lambang bilangan, dan penulisan singkatan dan akronim. Perhatikan data berikut.

(14) Foto dibawah ini memperlihatkan kebersamaan saya ketika saya masih kecil bersama kedua orang tua saya.

(15) Disaat ini saya belajar memanusiakan rasa manusia saya sebagai manusia. 
(16) Aku dan adikku lahir ditanggal yang sama, sementara ayah dan ibuku lahir pada bulan yang sama.

(17) Selain beberapa hal yang aku sebutkan diatas, ada beberapa sifat juga yang menurun dari orangtuaku padaku dan adikku.

(18) Jika dirumah biasanya makanan sudah tersedia dan tinggal mengambil saja, kini jika tidak memasak atau keluar untuk membeli makan maka tidak bisa makan hari itu.

(19) Dalam hidup tentu saja semua orang memiliki harapan dan cita-cita dikehidupan mereka.

(20) Keluarga kecil saya tinggal dirumah yang sederhana didaerah Ambarawa, angin disana masih segar untuk dirasakan.

Pada data (14) dan (20) terdapat kesalahan penulisan preposisi. Sesuai kaidah, harusnya preposisi di pada kata dibawah (data 14), disaat (15), ditanggal (16), diatas (17), dirumah (18), dikehidupan (19), dan didaerah (20) ditulis tidak serangkai dengan kata yang mengikutinya, sehingga menjadi di bawah, di saat, di tanggal, di atas, di rumah, di kehidupan, dan di daerah. Jadi, penulisan yang benar bisa dilihat pada kalimat (14a) dan (20a) berikut.

(14a) Foto di bawah ini memperlihatkan kebersamaan saya ketika saya masih kecil bersama kedua orang tua saya.

(15a) Di saat ini saya belajar memanusiakan rasa manusia saya sebagai manusia.

(16a) Aku dan adikku lahir di tanggal yang sama, sementara ayah dan ibuku lahir pada bulan yang sama.

(17a) Selain beberapa hal yang aku sebutkan di atas, ada beberapa sifat juga yang menurun dari orangtuaku padaku dan adikku.

(18a) Jika di rumah biasanya makanan sudah tersedia dan tinggal mengambil saja, kini jika tidak memasak atau keluar untuk membeli makan maka tidak bisa makan hari itu. 
(19a) Dalam hidup tentu saja semua orang memiliki harapan dan cita-cita di kehidupan mereka.

(20a) Keluarga kecil saya tinggal di rumah yang sederhana di daerah Ambarawa, angin di sana masih segar untuk dirasakan.

Berbeda dengan masalah pada data (14) dan (20), pada data (21) dan (22) berikut kesalahannya terletak pada penulisan prefiks di- pada kata ditanya dan penulisan antar sesama.

(21) Di tanya macam-macam dan bodohnya aku tetap datang.

(22) Selalu ada rasa toleransi yang sangat kuat antar sesama.

Prefiks di- pada kata di tanya sesuai kaidah harus ditulis dalam satu rangkaian dengan kata berikutnya, sehingga yang benar adalah ditanya. Demikian pula antar sesame pada data (22) harusnya ditulis serangkai menjadi antarsesama. Jadi, penulisan yang betul bisa dilihat pada kalimat (21a) dan (22a) berikut.

(21a) Ditanya macam-macam dan bodohnya aku tetap datang.

(22a) Selalu ada rasa toleransi yang sangat kuat antar sesama.

Kesalahan penulisan kata berikutnya, pada data (23) dan (24) terletak pada penulisan partikel pun pada kata siapapun dan sekarangpun. Kemudian, pada data (25), kesalahannya terletak pada penulisan enklitik $k u$ pada kata pada $k u$.

(23) Di bawah pohon bringin itu aku menanggis tersedu-sedu tidak ada siapapun yang peduli padaku.

(24) Hingga sekarangpun kami masih berteman dekat dan masih menjalin komunikasi yang baik.

(25) Keluarga $\mathrm{ku}$ bukan termasuk golongan keluarga yang mampu secara ekonomi atau kelas atas.

Sesuai kaidah, partikel pun pada kata siapapun dan sekarangpun pada data (23) dan (24) harus ditulis tidak dalam satu rangkaian dengan kata yang mendahuluinya, sehingga penulisan yang benar adalah siapa pun dan sekarang pun. Sebaliknya, pada data (25) enklitik -ku pada kata 
pada $k u$ sesuai kaidah dalam PUEBI harusnya ditulis serangkai sehingga yang betul adalah padaku. Penulisan yang betul dapat dilihat pada kalimat (23a) - (25a) berikut.

(23a) Di bawah pohon bringin itu aku menanggis tersedu-sedu tidak ada siapa pun yang peduli padaku.

(24a) Hingga sekarangpun kami masih berteman dekat dan masih menjalin komunikasi yang baik.

(12a) Keluargaku bukan termasuk golongan keluarga yang mampu secara ekonomi atau kelas atas.

Kesalahan berikutnya terkait dengan kesalahan penulisan kata adalah kesalahan penulisan angka pada data (26) - (28) berikut.

(26) Setiap 2 minggu sekali kami menginap dan menemaninya.

(27) Aku mulai masuk dalam dunia pendidikan pada usia 5 tahun.

(28) 14 hari menunggu hasil penggumuman aku ternyata diterima dari hampir 500 pendaftar aku termasuk yang beruntung.

Sesuai dengan aturan yang tersebut dalam Pedoman Umum Ejaan Bahasa Indonesia, harusnya pada data (26) dan (27) angka yang dapat ditulis dengan satu atau dua kata harus ditulis menggunakan huruf. Pada data (28), penulisan angka dengan posisi pada permulaan kalimat harusnya ditulis dengan huruf. Jadi, harusnya kalimat (26)-(28) sesuai kaidah harusnya ditulis menjadi (26a)-(28a) berikut.

(26a) Setiap dua minggu sekali kami menginap dan menemaninya.

(27a) Aku mulai masuk dalam dunia pendidikan pada usia 5 tahun.

(28a) Empat belas hari menunggu hasil penggumuman aku ternyata diterima dari hampir 500 pendaftar aku termasuk yang beruntung.

Kesalahan penulisan kata yang lain adalah kesalahan penulisan singkatan seperti terdapat pada data (29) sampai (32) berikut.

(29) Sewaktu sd, di mana pertama kali merasakan ujian nasional,ujian kelulusan, dan yang paling seru praktik.

(30) Jarak smp dengan rumahku agak jauh yaitu sekitar $1,5 \mathrm{~km}$ 
(31) Ibuku seorang guru tk, sebelumnya ibu membuka warung kecil untuk menambah penghasilan tetapi karena keterbatasan modal warung kami tutup.

(32) Ketika umur 4 tahun aku sudah masuk jenjang pendidikan dini atau biasa disebut paud.

Sejalan dengan aturan yang termaktub dalam Pedoman Umum Ejaan Bahasa Indonesia, singkatan nama badan/lembaga yang merupakan gabungan huruf awal tiap kata pada data (29)-(32) harusnya ditulis dengan huruf kapital seperti pada (29a)-(32a) berikut.

(29a) Sewaktu SD, pertama kali merasakan ujian nasional, ujian kelulusan, dan yang paling seru praktik.

(30a) Jarak SMP dengan rumahku agak jauh yaitu sekitar 1,5 km

(31a) Ibuku seorang guru TK, sebelumnya ibu membuka warung kecil untuk menambah penghasilan tetapi karena keterbatasan modal warung kami tutup.

(32a) Ketika umur empat tahun aku sudah masuk jenjang pendidikan dini atau biasa disebut PAUD.

Kesalahan berikutnya adalah kesalahan penulisan kata majemuk. Perhatikan data (33)(34) berikut.

(33) Ketika aku menunjukkan surat hasil ujian dan hasil prestasi, orangtuaku tidak percaya aku mendapat peringkat yang tinggi di kelas.

(34) Saya dan kedua kakak saya tentunya sangat bangga dan berterimakasih akan segala pengorbanan yang telah mereka lakukan untuk kami semua.

Sesuai kaidah tata tulis dalam Pedoman Umum Ejaan Bahasa Indonesia (2016), kata majemuk ditulis terpisah. Jadi, penulisan yang betul seperti pada (33a) dan (34a) berikut.

(33a) Ketika aku menunjukkan surat hasil ujian dan hasil prestasi, orang tuaku tidak percaya aku mendapat peringkat yang tinggi di kelas.

(34a) Saya dan kedua kakak saya tentunya sangat bangga dan berterima kasih akan segala pengorbanan yang telah mereka lakukan untuk kami semua.

Kesalahan Pemakaian Tanda Baca 
Dalam penulisan tugas autobiografi dari para mahasiswa Prodi S-1 Sastra Indonesia Angkatan 2019 kelas A juga masih terdapat kesalahan pemakaian tanda baca. Perhatikan data (35) sampai data (38) berikut.

(35) Selain ikut osis, aku juga ikut Rohis (rohani islam) serta organisasi di luar sekolah. Yaitu forum anak dan forum kesatuan pelajar kota.

(36) Selama seminggu, kami mengunjungi beberapa tempat wisata. Seperti Tanah Lot, Pure Uluwatu, Bedugul, Batu Malang, Gunung Bromo dan lainnya.

(37) Beberapa kelebihanku antara lain: mudah menghapal, cukup penyabar, tidak tegaan, pekerja keras, rajin, tepat waktu dan sering mengalah demi orang lain.

(38) Selama enam belas tahun saya hidup bersama keluarga kecil tanpa ada saudara, hal itu membiasakan saya untuk hidup sendiri dengan perhatian tertuju kepada saya.

Sesuai dengan kaidah yang termuat dalam Pedoman Umum Ejaan Bahasa Indonesia, harusnya penulisan yang betul seperti terdapat pada kalimat (35a) - (38a).

(35a) Selain ikut OSIS, aku juga ikut Rohis (Rohani Islam) serta organisasi di luar sekolah, yaitu forum anak dan forum kesatuan pelajar kota.

(36a) Selama seminggu, kami mengunjungi beberapa tempat wisata, seperti Tanah Lot, Pure Uluwatu, Bedugul, Batu Malang, dan Gunung Bromo.

(37a) Beberapa kelebihanku antara lain: mudah menghapal, cukup penyabar, tidak tegaan, pekerja keras, rajin, tepat waktu, dan sering mengalah demi orang lain.

(38a) Selama enam belas tahun saya hidup bersama keluarga kecil tanpa ada saudara. Hal itu membiasakan saya untuk hidup sendiri dengan perhatian tertuju kepada saya.

Kesalahan berikutnya adalah pada penulisan kata yang seharusnya menggunakan tanda petik (") dan tanda hubung (-) pada data (39) dan (40) berikut, tetapi tidak ada tanda baca tersebut.

(39) Lagu yang saya bawakan adalah lagu bunda dan burung kutilang.

(40) Meskipun ada banyak kesalahpahaman ataupun masalah lainnya, kami semua tidak bisa jauh jauh lebih dari satu hari.

Penulisan yang betul bisa dilihat pada (39a) dan (40a) berikut.

(39a) Lagu yang saya bawakan adalah lagu "Bunda" dan "Burung Kutilang".

(40a) Meskipun ada banyak kesalahpahaman ataupun masalah lainnya, kami semua tidak bisa jauh-jauh lebih dari satu hari.

Kesalahan Penulisan Unsur Serapan 
Kesalahan lain yang ada adalah kesalahan penulisan kata-kata serapan dari bahasa asing. Perhatikan data (41)-(44) berikut.

(41) Saya memiliki bakat dalam mengekspresikan diri dan salah satunya adalah bermain acting.

(42) Selama enam tahun berada di SD, banyak moment dan peristiwa yang terjadi.

(43) Kelas lima SD temanku mengajakku membuat sebuah genk beranggotakan empat orang termasuk aku.

(44) Namun, saya tetap optimis dan yakin bisa membuat team yang saya pimpin menjadi yang terbaik.

Penulisan kata acting, moment, genk, dan team pada data (41)-(44) tidak sesuai dengan kaidah tata tulis yang terdapat dalam PUEBI. Penulisan yang benar sesuai dengan PUEBI dapat dilihat pada (41a)-(44a) berikut.

(41a) Saya memiliki bakat dalam mengekspresikan diri dan salah satunya adalah bermain akting.

(42a) Selama enam tahun berada di SD, banyak momen dan peristiwa yang terjadi.

(43a) Kelas lima SD temanku mengajakku membuat sebuah geng beranggotakan empat orang termasuk aku.

(44a) Namun, saya tetap optimis dan yakin bisa membuat tim yang saya pimpin menjadi yang terbaik.

\section{Simpulan}

Dalam pengerjaan tugas penulisan autobiografi yang dilaksanakan oleh para mahasiswa Prodi S-1 Sastra Indonesia Angkatan 2019 Kelas A, apabila dinalisis dari sudut ejaan dengan mengacu pada Pedoman Umum Ejaan Bahasa Indonesia (PUEBI) ternyata masih terdapat kesalahan. Kesalahan-kesalahan itu meliputi kesalahan pemakaian huruf, penulisan kata, pemakaian tanda baca, dan penulisan unsur serapan. Untuk lebih mengurangi tingkat kesalahan, pemahaman aturan-aturan yang secara jelas ada dalam Pedoman Umum Ejaan Bahasa Indonesia (PUEBI 2016) sangat diperlukan. Selain itu, kecermatan dan ketelitian ketika menyusun sebuah tulisan juga sangat perlu diperhatikan.

\section{Daftar Pustaka}

Alwi, Hasan dkk. 1998. Tata Bahasa Baku Bahasa Indonesia. Edisi Ketiga Jakarta: Balai Pustaka. 
Mustakim. 1996. Tanya Jawab Ejaan Bahasa Indonesia untuk Umum. Jakarta: PT Gramedia Pustaka Utama.

Sudaryanto. 1993. Metode dan Aneka Teknik Analisis Bahasa: Pengantar Penelitian Wahana Kebudayaan Secara Linguistis. Yogyakarta: Duta Wacana University Press.

Tim Pengembang Pedoman Bahasa Indonesia. 2016. Pedoman Umum Ejaan Bahasa Indonesia. Jakarta: Badan Pengembangan dan Pembinaan Bahasa. 